\title{
Er Tyrkia USAs nye modell i Midtøsten?
}

Sent i 2003 lanserte USA sin visjon for utviklingen av demokrati i Midtøsten, det såkalte Greater Middle East Initiativ (GMEI), som et ledd $i$ krigen mot terror. Det nye trusselbildet åpnet opp strategiske muligheter for Tyrkia, og ga det nyvalgte Rettferd- og utviklingspartiet,AKP,en gyllen mulighet til å profilere Tyrkia i ny drakt. 
TEKST: Pinar Tank

АKР, SOM ком TIL makten i november 2002, var et konservativt muslimsk parti og rettet umiddelbart søkelyset mot verdien av Tyrkias muslimske identitet. For eksempel ble det for første gang lagt vekt på landets islamske røtter som en fordel, og ikke ulempe, i medlemskapsforhandlinger med EU. Med AKP ved makten kunne Tyrkia legitimt tilby seg selv som en brobygger mellom øst og vest i Huntingtons såkalte “sivilisasjonskollisjon”. Denne nye tolkningen av Tyrkias identitet ble støttet av USA, som stadig oftere refererte til Tyrkia som selveste modellen for hvordan demokrati og moderat islam kunne forenes.

Denne fremstillingen av landet som en bro mellom øst og vest var ikke fremmed, verken for tyrkiske politikere eller for omverdenen. Tyrkia har lenge markedsført seg selv som et land hvor to verdensdeler møtes. I reportasjer om Tyrkia er broen over Bosporos-stredet i Istanbul ofte brukt som symbol på dette. Landets historie - en fortid forankret i Østen, men en fremtid oppsøkt i Vesten - forsterker yterligere denne fortolkningen.

Gitt landets beliggenhet har tyrkere alltid ansett landet som både del av Europa og av Midtøsten. Men denne oppfatningen er bare delvis sann. Til tross for at 99\% av tyrkerne er muslimer, har den sekulære eliten vært svært opptatt av å tone ned Tyrkias muslimske identitet til fordel for den vestlige. Dette er i overensstemmelse med ideologien til landsfaderen Kemal Atatürk - grunnleggeren av den moderne republikken. Kemalistenes reformer siktet på å skape en ideologisk revolusjon hvor vestlig kultur og sivilisasjon skulle danne grunnlaget for den moderne staten. Vestliggjøringen ble implementert på alle plan, fra alfabetet og utdannelsessystemet til vestlige klesstiler og klassisk musikk. Prosessen er ofte omtalt som et prosjekt i sosial ingeniørvirksomhet (social engineering).

Tidlig i vestliggjøringsprosessen fikk det tyrkiske militæret rollen som "beskyttere" av den kemalistiske revolusjonen, og ved flere anledninger har de intervenert for å forsvare statens integritet og sekularitet. ${ }^{\mathrm{I}}$ Deres plikt til å gripe inn er grunnlovsfestet. Senest i I997 ble et tidligere muslimsk parti, Velferd (Refah), avsatt i det som ble kalt et postmoderne kupp. Velferdspartiet hadde trådt over militærets røde linjer, og ble dermed ansett for å være en trussel mot Tyrkias sekulære stat. ${ }^{2}$ Dette reiser spørsmålet: Hvordan kan Tyrkia, et land der statens sekularitet er forsvart ved militær makt, la seg "omdefinere" til et “muslimsk demokrati”? Og ikke minst, kan 
Tyrkias rolle som en "modell" ovenfor den muslimske verden berettiges?

\section{Identitet og sikkerhet}

I det moderne Tyrkia har båndene mellom identitet og sikkerhet vært nært knyttet, og Tyrkia har bevisst valgt å binde seg til Vesten av både ideologisk og, ikke minst, sikkerhetspolitiske hensyn. Spesielt under den kalde krigen var det viktig for Tyrkia å vise sin forpliktelse overfor Vesten for å oppfylle sine egne sikkerhetspoliske behov, noe som ytterligere bidro til å definere landets identitet som vestlig. Tyrkia ble medlem av NATO i I952, og har siden vært en av USAs mest lojale støttespillere. Men det moderne Tyrkias vestlige orientering har vært til skade for dets regionale relasjoner. Landet har historisk sett vært lite solidarisk med Midtøsten. Eksempelvis valgte Tyrkia under fremveksten av panarabisk nasjonalisme å ignorere sine naboers ambisjoner: Tyrkia stemte med Frankrike i FN mot Algerie under den algeriske frigjøringskrigen, og var den første muslimske stat til å anerkjenne Israel. Forholdet til Syria var anspent etter konflikten over Alexandrette (Hatay) i I939, og forholdet til Egypt ble kjøligere etter tyrkisk anerkjennelse av Israel. ${ }^{3}$

Tyrkias geopolitiske rolle var dermed gitt under den kalde krigen, noe som gjorde at landet i ettertid fikk en midlertidig "geopolitisk krise". Golfkrigen i I99I ble redningen. President Özal engasjerte Tyrkia i krigen på de alliertes side til tross for at det var bred opposisjon blant politikere, befolkningen, og ikke minst militæret, mot tyrkisk innblandning. Han forsto at dette var en unik mulighet til å omdefinere Tyrkias geopolitiske betydning for Vesten. Ved å plassere Tyrkia lenger øst, bidro han til å øke landets verdi for Vesten. ${ }^{4}$ Ikke minst ble landet dratt mer inn i det regionale sikkerhetspolitiske samarbeidet, grunnet det kurdiske spørsmålet, noe som fikk økt oppmerksomhet etter Golfkrigen og som var av felles interesse for Tyrkia, Irak, Iran og Syria. Dette ble vendepunktet for en mer aktivistisk rolle i Midtøsten for Tyrkia som inntil da hadde avstått fra regional innblandning. Samtidig ble de nære bånd til USA ytterligere forsterket noen år senere ved at landet inngikk en avtale med Israel i I996 om militært etterretningssamarbeid. Denne avtalen befestet samarbeidet med USA, men var skadelig for Tyrkias forhold til sine arabiske naboer (med unntak av Egypt og Jordan). ${ }^{5}$ Resultatet var at landet ofte ble ansett som USAs nikkedukke. Det er åpenbart problematisk å fremheve Tyrkia som modell for den arabiske verden, slik USA har forsøkt, hvis det ikke er aksept for dette blant de landene USA ønsker å påvirke.

\section{AKPs rolle}

I følge Peter van Ham, som låner konseptet fra næringslivet, er en stats identitet en "merkevare" som skapes gjennom andre staters ideer om det landet. ${ }^{6}$ For at argumentet om Tyrkias identitet som et vellykket muslimsk demokrati skal "markedsføres" må det være troverdig vis-à-vis den arabiske verden. Gitt den sekulære statens avvisning av Tyrkias muslimske fortid, har dette vært vanskelig. Men siden 2002 har AKPs politikk påvirket denne debatten betydelig. For det første har partiet gjentatte ganger poengtert at de definerer seg selv som et "muslimsk demokratisk" parti på lik linje med kristen-demokratene i Europa og ikke som et "islamistisk" parti. For det andre har de hatt medlemskap i EU som 
sin utenrikspolitiske prioritering. De har lyktes i å igangsette en vanskelig reformprosess med omfattende reformer blant annet vedrørende menneskerettigheter, kurderspørsmålet og militærets rolle. Dette har kulminert i EUs fastsettelse av en dato for åpningen av medlemskapsforhandlinger i oktober i år. Ved å kjempe hardt for EU-medlemskap har AKP fått økt tillit blant den sekulære eliten.

Men det har også vært utenrikspolitiske uromomenter, spesielt under håndteringen av Irak-krisen. Det stødige tyrkiskamerikanske forholdet ble rystet I. mars 2003 da det AKP-kontrollerte parlamentet med et flertall på fire stemmer nektet utplassering på tyrkisk jord av amerikanske soldater på vei til Irak. Saken ble forverret av kommentarene til viseforsvarssekretær, Paul Wolfowitz, som kritiserte det tyrkiske militæret for å ikke ha påtatt seg en lederskapsrolle for å sikre støtte for USAs politikk i Irak.7 Wolfowitz sin skuffelse var desto større siden han var en av Tyrkias sterkeste støttespillere i Bush-administrasjonen. Bare ett år tidligere hadde han argumentert sterkt for at Tyrkia kunne spille en nøkkelrolle etter 9/ıI: “To win the war against terrorism, we have to reach out to the hundred of millions of moderate and tolerant people in the Muslim world. In the United States we understand that Turkey is a model for those in the Muslim world who have aspirations for democratic progress and prosperity". 8

Paradoksalt nok var avvisningen av amerikanske soldater med på å øke Tyrkias troverdighet $\mathrm{i}$ rollen USA hadde tiltenkt landet. Med AKP ved roret og en ny retning i Tyrkias politikk vis-à-vis USA på Irakspørsmålet økte modellens legitimitet. ${ }^{9}$ Samtidig var AKP opptatt av å ikke bruke ordet "modell". Under en konferanse i Istanbul i juni 2004, påpekte utenriksminister Gül at Tyrkia kunne vise vei, men at hvert enkelte lands demokratiske utvikling nødvendigvis var rotfestet i dets egen kultur. ${ }^{10}$ Trass i dette var den prominente

\section{Paradoksalt nok var avvisningen av amerikanske soldater med på å øke Tyrkias troverdighet $i$ den rollen USA hadde tiltenkt landet.}

rollen tiltenkt Tyrkia i regi av Greater Middle East Initiative tydelig når landet var invitert til å delta på G8-toppmøtet i USA i juni 2004, som delformann i toppmøtets "demokratiske assistansedialog".

AKP var også bevisst på å fortsette Tyrkias mer aktivistiske regionale rolle. Et eksempel på dette er utviklingen i forholdet mellom Syria og Tyrkia. Det begynte å bedre seg etter utvisningen av PKK-lederen Abdullah Öcalan fra Syria i I998 før AKPs regjeringen kom til makten. Men det var under AKP-regjeringen at det første statsoverhodebesøket fra Syria fant sted i januar 2004. Gitt begge lands frykt for utviklinger i det kurdiske spørsmålet i Nord-Irak, har forholdet forsterket seg. Statsminister Erdogan har til og med tilbudt tyrkisk megling mellom Syria og Israel i håp om å gjenopprette fredsforhandlinger mellom de to statene. Tidlig i 2004 gikk han enda lenger ved å tilby Tyrkia som megler også mellom Palestina og Israel. Til tross for at dette ikke ble noe av, var tanken bak forslaget sannsynligvis at de nære militære og økonomiske bånd til Israel vil 
muliggjøre Tyrkias rolle vis-à-vis Israel mens AKPs muslimske identitet vil berettige Tyrkias meglerrolle i forhold til den arabiske verden. Nytteverdien av Tyrkias forhold til Syria - som en kanal mellom landet og USA - kommer sannsynligvis til å øke ettersom president Bush har satt Syria på toppen av sin liste av stater som støtter terrorisme. II Interessant nok er Tyrkias politikk, både når det gjelder Syria og Iran, mer lik EUs forsøk på å etablere en konstruktiv dialog med bruk av insentiver, enn USAs bruk av trusler.

Samtidig var landets forsonende rolle som et muslimsk demokrati i krigen mot terror dypt mislikt av militante islamister. Det blodige beviset på dette kom i november 2003, da $6_{3}$ mennesker mistet livet i flere bombeangrep i Istanbul utført av islamistiske terrorgrupper. Etter denne episoden, refererte President Bush til Tyrkia som den nye fronten i krigen mot terror. $^{12}$

\section{En problematisk identitet}

Med tanke på den sekulære elitens frykt og militærets vedvarende viktige plass i samfunnet, er det klart at utviklingen av en sterk muslimsk identitet for Tyrkia ikke vil være lett å akseptere. Den er heller ikke alltid ansett som fordelaktig i utenrikspolitisk sammenheng. I forhold til EU, for eksempel, er vektleggingen på Tyrkias muslimske identitet et tveegget sverd. På den ene siden er det tydelig at EU ved å invitere Tyrkia til å åpne forhandlinger i oktober 2005 kan markedsføre seg selv som en multikulturell region, og ikke et kristent "festning Europa". Men det er de som motsetter seg denne tankegangen. I 2002 varslet arkitekten av EUs grunnlov, Giscard D'Estaing, at tyrkisk medlemskap ville bety "slutten på Europa". En lignende uttalelse kom fra den tidligere nederlandske EU-kommissæren, Fritz Bolkestein, som advarte mot innlemmelsen av Tyrkia i EU fordi det ville medføre til ytterligere "islamisering av Europa". Begge setter ord på en økende mistro i den offentlige opinionen mot muslimer i Europa. Mens Tyrkias eventuelle tiltredelse i EU kan bidra, i minste fall symbolsk, på å øke følelsen av tilhørighet blant Europas ikke-vestlige innvandrere, kan det også øke skepsisen blant dem som frykter et Europa truet innenfra.

Enda viktigere er den identitetsbyggende kraften som ligger i utformingen av en utenrikspolitisk profil. ${ }^{13}$ Den sekulære eliten er klar over at landets internasjonale profil, i dette tilfelle som et muslimsk land, kan bidra til fremveksten av religiøsitet internt i samfunnet, og frykter følgene av en slik utvikling. Dette vil kunne føre til økt press for å oppheve forbudet mot religiøse symboler (som bruk av skaut i det offentlige rom), noe som er et svært sårbart tema for militæret. Fra tid til annen tar Erdogan opp denne diskusjonen, som er presset fram av grasrota i partiet, men AKP er klar over at de må trå varsomt i forhold til militærets røde linjer hvis landet skal fortsette å utvikle seg i en demokratisk retning. ${ }^{14}$ For like viktig som AKPs muslimske skussmål i rollen som modell er den demokratiske fremgangen i Tyrkia.

\section{Konklusjon}

Huntington refererer til Tyrkia som en "opprevet land" på grunn av dets tvetydige identitet. ${ }^{15}$ Til tross for at dette utrykket lyder negativt i nasjonal identitetssammenheng er det ikke udelt negativt for Tyrkia. Under AKP har Tyrkia klart å utnytte sin 
fleksible identitet til egen geopolitisk fordel. Hvorvidt dette fortsetter er avhengig av innenrikspolitisk dynamikk og internasjonale utviklinger. Internt må AKP være forsiktig i bruken av religion slik at det ikke blir ansett som en trussel mot statens sekularitet, mens de eksternt kan markedsføre Tyrkia som et muslimsk demokrati så lenge det styrker Tyrkias geopolitiske posisjon. I tillegg er det større internasjonale utfordringer i horisonten. Disse inkluderer Tyrkias håndtering av NordIrak-spørsmålet og, i en mindre grad, utviklingen av forholdet til Kypros (og dermed EU). Begge to er områder hvor den sekulære eliten, spesielt militæret, har spilt en betydelig rolle og hvor nasjonale følelser fort settes i sving hvis stilt overfor en oppfattet trussel. Hvis sikkerhetsbildet virker truende, for eksempel ved større kurdisk kontroll av Kirkuk, kan det sette den demokratiske utviklingen på spill. Disse utfordringene må løses på måter som er tilfredsstillende både for aktører i Tyrkia og for det internasjonale samfunn forøvrig. Veien som AKP har valgt for Tyrkia, som modell for Midtøsten på USAs oppfordring, er klar, hvor den vil lede er vanskeligere å forutse.$$
\text { - } f \cdot
$$

Forfatteren vil takke Mona Abdel-Fadil, Naima Mouhleb, og Julia Øverås for redigering og språkvask.

I Den mest presise beskrivelsen av det tyrkiske militærets juridiske rolle og forpliktelser, finnes i de tyrkiske bevæpnede styrkers interntjenestelov, artikkel 35, datert januar I96I, som pålegger dem ansvaret for beskyttelsen av den tyrkiske republikkens integritet og sekularitet, slik det blir beskrevet i grunnloven. For en mer omfattende diskusjon av dette, se Gareth Jenkins (200I), «Context and Circumstance: The Turkish Military and Politics», Adelphi Paper 337. The International Institute for Strategic Studies, London, Oxford University Press.
2 Ben Lombardi (1997), "Return of the Reluctant Generals", Political Science Quarterly, II2, Summer, http://www.epn.org/psq/lombardi.html.

3 Ömer Taspinar (2003), “An Uneven Fit? The 'Turkish' Model and the Arab World", Analysis Paper No. 5, Washington DC: Saban Center for Middle East Policy at the Brookings Institution.

4 Duygu Bazoglu Sezer (1996), "Turkey in the New Security Environment in the Balkan and Black Sea Region" i V. Mastny and C. Nation (red.) «Turkey Between East and West», Boulder: Westview Press, s. 77.

5 Pinar Tank (200I), "Turkey as a 'Special Case' for the EU”, Security Dialogue, 32/2, s. 217-230.

6 Peter van Ham (200I), "The Rise of the Brand State", Foreign Affairs, $80 / 5$, s. 2-6.

7 TurkishPress.com, "Transcript: Wolfowitz Criticizes Turkey for Not Backing U.S. On Iraq", I4. mai 2004. http://www.turkishpress.com/turkishpress/news.asp? ID=I0209.

8 Paul Wolfowitz (2002): "Turgut Özal Memorial Lecture", Washington Institute for Near East Studies, 15. mars. http://www.washingtonfile.net/2002/March/MarchI4 /EUR405.HTM.

9 Selvsagt var det betryggende for den sekulære eliten at Tyrkias stilling, til tross for å være imot USA, var nærmere den europeiske holdningen til Irakkrigen.

Io Address by Minister of Foreign Affairs and Deputy Prime Minister Abdullah Gül at the Conference on "The Transatlantic Alliance at a New Crossroads", Istanbul, 26 June 2004 .

II New York Times, "President Bush's State of the Union Address", 3 February 2005, www.nytimes.com/2005/ 02/03/politics/o3btext.html.

I2 Dana Milbank (2003): "Bush Calls Turkey a 'Front' in the War on Terror", Washington Post, 22. november.

I3 Her er det klare paralleller som kan trekkes mellom utformingen av Norges utenrikspolitiske profil som en humanitær makt og norsk identitetsfølelse.

I4 Pinar Tank (2005), "Political Islam in Turkey: A State of Controlled Secularity", Turkish Studies, 6/I, S. 5-2I.

I5 Samuel Huntington (1996), «The Clash of Civilisations and the Remaking of the World Order», New York: Simon \& Schuster, s. 74. 